\title{
The Formation of Malaysia: Advancing the Theses of Decolonization and Competing Expansionist Nationalisms
}

\author{
D. S. Ranjit Singh \\ School of International Studies \\ Universiti Utara Malaysia, Sintok, Malaysia \\ Tel: 60-4-928-8535 E-mail: ranjit@uum.edu.my
}

Received: July 10, 2014 Accepted: August 2, 2014 Published: February 1, 2015

doi:10.5296/jmr.v7i2.6933 URL: http://dx.doi.org/10.5296/jmr.v7i2.6933

\begin{abstract}
The formation of Malaysia is an old topic but in the past its formation has been explained basically in terms of the expansion theory and the security theory. With the release of new documents on the subject by the British National Archives (previously known as the Public Record Office), in recent years, much more information, hitherto unavailable, is now at the disposal of researchers. A careful study of these documents reveals that 'Malaysia' was in essence a British Colonial scheme hatched in 1942 for the eventual decolonization of Southeast Asia. It is therefore the intention of this paper to advance the view that though the British failed to create their 'Grand Design' due to political exigencies on the ground, the formation of Malaysia on 16 September 1963 was in fact undertaken to solve the problems of British decolonization as well as to cater to the phenomena of competing expansionist nationalisms in post-colonial Southeast Asia rather than fulfilling the needs of the narrower expansion and security theories.
\end{abstract}

Keywords: Formation of Malaysia, Decolonization, Expansionist nationalisms, Security theory, Grand design 


\section{Introduction}

A great number of studies on the formation of Malaysia have been undertaken in the past, but the explanation has chiefly anchored on the security and the expansion theories (Noordin Sopiee. 1976. 125-127). The release of new documents on the subject by the British National Archives in recent years has shed new insight on the issue. A careful study of these documents reveals that 'Malaysia' was in essence a British Colonial Scheme hatched in 1942 for the eventual decolonization on Southeast Asia. However political exigencies on the ground, especially the unexpected early achievement of independence by Malaya in 1957, derailed British plans for a 'Grand Design' in Southeast Asia. The British then decided to divest themselves of the remaining territorial possessions in the region, but found it unfeasible to do so as the units were too small and too weak to survive on their own. The formation of Malaysia on 16 September was therefore in fact undertaken to solve the problems of British Decolonization as well as to cater to the phenomena of competing expansionist nationalisms in post-colonial Southeast Asia rather than providing a solution to the contingencies of the security theory and the lure of the expansion theory.

\section{The Colonial 'Malaysia' Scheme - The 'Grand Design'}

The formation of Malaysia on 16 September 1963 was the culminating point of the convergence of two separate schemes of different orientations. One was based on colonial plans and needs; and the other, on expansionist nationalisms in Southeast Asia. Since the signing of the Atlantic Charter in August 1941, Britain committed itself to the principle of leading dependent territories toward the goal of self-government (the policy of decolonization) after the war. Another principle which also became a pillar of post-war colonial policy and a pre requisite for achieving the first goal, was the intention to integrate small units into bigger political blocs in the interest of administrative efficiency, economic development, political stability and defence viability (A. J Stockwell. 1979: 17-23; D. S. Ranjit Singh. 1998: 27-28). As far as British possessions in the Malayan-Borneo ware concerned, these two principles were incorporated into future policy planning which began in 1942 by the Eastern Department of the Colonial Office headed by G. Edward Gent. In this context, both the Colonial Office and the Foreign Office in 1942 laid plans for a 'Grand Design' in Southeast Asia after the Second World War which called for the creation of a 'union', a 'federation'; a 'confederation' or a 'dominion', of all British territories in the Malayan-Borneo region as a precursor for the granting of self-government. This large union or federation was to include the Malay states, the Straits Settlements and the British Borneo territories of North Borneo, Sarawak and Brunei. (C. O. 825/35 pt. 1 No 55104/1942, quoted in A. J. Stockwell. 1979: 22-23. Also see Albert Law. 1991: 37-38). This 'Grand Design' which may be appropriately named as the 'Colonial Malaysia Scheme' was to be achieved gradually in stages beginning with political integration in two separate blocs, that is, between Malaya and Singapore on the one hand, and between the Borneo territories on the other. Confirming this line of action, J. D. Higham of the Colonial Office minuted on 20.1.53 as follows: (J. D. Higham's Minute, 20.1.53 C. O. 1022/61. Item 19. 192) 
Our original idea was that Malaya and Singapore would form one bloc and Sarawak, North Borneo and Brunei, another, and that the two blocs might then merge into some sort of confederation.

From 1946 to 1949, and even later, the British Government wished to push ahead with the process of first undertaking integration within the two blocs separately. However political, strategic and economic exigencies and the desire to push the Malayan Union proposals in Malaya, managing the Anti-Cession movement in Sarawak, and the problems pertaining to political, economic and social developments in both the regions hindered all attempts to bring about any union within these blocs (D. S. Ranjit Singh. 1998: 29-40).

Seeing that integration in two separate blocs was not working, the British Government revived the 'Grand Design' or the 'Colonial Malaysia Scheme' idea in 1949. Towards this end the British Government created the post of the British Commissioner-General for Southeast Asia to act as a coordinating body in the region. The man chosen for the job was Malcolm MacDonald. The new initiative was reflected in a dispatch from the Secretary of State for the Colonies, Creech-Jones to the Commissioner-General dated 12 November 1949. The Commissioner-General was instructed as follows: (C. O. 1022/61 Item 19: 191)

You are directed... to promote the co-ordination of policy administration between the Governments in your area of authority. In the course of time some closer political cooperation may be desirable, and you will advise the Secretary of State for the Colonies on this question from time to time.....

\section{A British Dominion of Southeast Asia}

The Commissioner-General was also advised to create a 'climate of public opinion' which would favour integration in the region. The Colonial Office considered it most judicious and imperative that '... the initiative was to appear to come from local leaders of public opinion'. (C. O. 1022/61 Item 30. 158. Colonial Office Memorandum. 10.3.1953). Though trying very hard, Malcolm MacDonald, achieved little success from 1949 to 1951. In 1951, he began to introduce new innovations, the most important being the setting up of branches of the Commonwealth Parliamentary Association (CPA) in the various British territories in the Malayan-Borneo region. By this move, MacDonald was able to foster much regional solidarity and goodwill among the local leaders through the mechanism of CPA meetings. (C. O. 1022/61. Item 1. 232. Commissioner General-SEA's Secret Savingam 181. 29.1.1951). In the light of strong support especially from unofficials for a wider regional integration, MacDonald began to push vigorously for the realization of the 'Grand Design' in 1952. (C. O. 1022/61. Item 7. 220-221. Malcolm MacDonald's Secret Savingam. 29.1.1952). He explained his plans as follows: (C. O. 1022/61. Item 15. Commissioner General-SEA's Secret Savingam 73. 10.6.1952) 
In a recent off-the-record discussion with about twenty leading British, Asian and American journalists, I said frankly that our long-term aim in British South-East Asia is the creation of a self-governing dominion of all these territories within the Commonwealth.

The Commissioner-General sought Colonial office endorsement for his wider scheme. Some officials in the Colonial Office were rather sceptical of MacDonald proposals in the light of past opposition in the region toward integration of any sort. Paskin of the Colonial Office echoed this skeptimism in his minutes as follows: (Paskin's minute of 7.2.1954, C. O. 1022/61. Item 7. P. 9)

It is surprising to learn that it is now felt that more rapid progress in bringing about a closer association between Singapore and the Federation can be achieved by attempting at the same time to bring in these relatively backward territories [the British Borneo territories]

Other senior members of the Colonial Office, especially J. D. Higham however supported MacDonalds plan for a wider association. Various arguments were advanced for the new line taken by the Commissioner-General. These do not appear in MacDonald's Savingams, but in Colonial Office correspondence. Briefly they may be summarized as follows. It was felt in early 1952 that a wider association of the five territories would be more attractive to the Federation as the Borneo territories had a non-Chinese dominated population. The fears of the Malays of incorporating a large Singapore Chinese majority would be somewhat allayed. In Singapore some enlightened unofficials expresses doubts about the ability of the island to survive as an independent entity in the long-run and began to entertain the idea of closer association probably "within the framework of a Malaya-Borneo Confederation". There was also the fear expressed in Colonial Office circles that it would be dangerous to leave the sparsely populated and under-developed Borneo territories on their own "adjacent to a potentially acquisitive Indonesia" (see Brief for the Secretary of State's Visit, 20.11.1951, C. O. 1022/61. Item 2. P. 231; Memorandum on Political Objectives in British Territories of Southeast Asia, Colonial Office 10.3.1953, C. O. 1022/61. Item 30. P. 160, and J. D. Higham's Minute of 20.1.1953, C. O. 1022/61. Item 19. P. 193). Indeed, Indonesia under Sukarno had grand ideas of reviving the glory of the Majapahit Empire, and thus had designs on British Borneo as well as other regions of Southeast Asia, including West Irian. (Gerg Poulgrain. 1998: 185-189, 231-235; D. G. E. Hall. 1981: 930-932).

The Commissioner-General's efforts however did not bear fruit. By the early months of 1953 , support for the Grand Design or the British Dominion began to dissipate mainly as a result of uncompromising attitudes of British colonial officials in Malaya and Singapore. The ongoing animosity between top British administrators of these two states forced the Colonial Office to abandon the idea of forming an overall British Dominion of Southeast Asia in favour of the pre-1951 formula of encouraging the formation of separate political blocs. While the Colonial 
Office concentrated it efforts in improving relations between Malaya and Singapore, a strong initiative commenced in the Borneo region in 1953 to promote greater administrative coordination between North Borneo, Sarawak and Brunei with a view of their "ultimate federation".

Political developments in Malaya too began to take fundamental decision-making out of the hands of the colonial masters. The formation of the Alliance Party composed of UMNO, MCA and MIC in 1954 and its resounding victory in the 1955 elections to the Federal Council effectively placed Malayan leaders in charge of their destiny. Under the dynamic leadership of Tunku Abdul Rahman, UMNO and the Alliance, Malaya thus began to move towards independence at a pace far ahead of the British "time-table". In this context, the views of Tunku Abdul Rahman and UMNO concerning the Malaya-Singapore merger and the wider Colonial Malaysia Scheme became decisive.

Although there grew a strong body of opinion in Singapore in 1954 and 1955 advocating merger with the Federation of Malaya, Tunku and UMNO strongly opposed such a union. They feared that the Malays would be outnumbered by the addition of over a million Chinese, that the Malays would lose political dominance and that Malaya's security would be seriously threatened. The British, taking stock of the situation could not countenance merger in the face of UMNO's rejection. (Noordin Sopiee. 1974: 103-110).

As far as the Colonial Malaysia Scheme was concerned, Tunku Abdul Rahman in fact lent support to the idea in 1955 and 1956, but the format was to be "Greater Malaya" which was to be established in the future after Singapore, Sarawak, Brunei and North Borneo had achieved independence (Noordin Sopiee. 1976: 129-130). For the moment, however, in 1956, Tunku was more concerned in winning independence for Malaya in a hurry and did not want any scheme of merger or territorial expansion to derail this supreme objective. 'At this stage', he declared in 1956, 'it is wise to be prudent like Kamal Ataturk who resolutely opposed territorial expansion in favour of improving Turkey itself first' (Singapore Standard, 23 June 1956. Quoted in Noordin Sopiee. 1976: 130). Thus when Malaya achieved independence in 1957, ahead of the colonial "time-table" and ahead of Singapore, the British Grand Design was rendered untenable and therefore remained unfulfilled. The idea of Malaysia however remained alive both in the minds of the British and Tunku Abdul Rahman and finally came to fruition in 1963 as a culmination of the combined forces of decolonization and expansionist Southeast Asian nationalisms.

\section{Tunku's Malaysia}

After achieving independence for Malaya in 1957, Tunku Abdul Rahman again broached the subject of forming Malaysia on 27 May 1961. Speaking at a luncheon in Singapore given by the Foreign Correspondents of Southeast Asia at the Adelphi Hotel, the Tunku made his famous speech on that fateful day as follows: (Department of Information Malaya. 1962.) 
Malaya today as a nation realizes that she cannot stand alone and in isolation.... Sooner or later she should have an understanding with Britain and the peoples of the territories of Singapore, North Borneo, Brunei and Sarawak. It is premature for me to say now how this closer understanding can be brought about, but it is inevitable that we should look ahead to this objective and think of a plan whereby these territories can be brought closer together in political and economic cooperation.

Various theories have been advanced explaining Tunku's consideration for the formation of Malaysia. Noordin Sopiee postulates two theories. One is the 'expansion theory' and the other the 'security theory'. According to the 'expansion theory', the Tunku first conceived of the idea around 1955 and later in 1957, when British officials in Borneo were contemplating the formation of a northern Borneo federation. The Tunku asked the British Government to bring about the incorporation of British Borneo into a Malaysian federation, but the British Government wanted the inclusion of Singapore as well. The Tunku, however, was unwilling to do this because of the fear of Chinese domination. In its extreme form the 'expansion theory' postulates that Singapore was only brought into the Malaysia plan as a means to incorporate the Borneo territories into the Federation.

The 'security theory', on the other hand, contends that the Tunku's main consideration was the danger of Singapore turning communist in 1961. This would pose a security threat to Malaya and therefore he wanted Singapore's incorporation into the Federation. The Borneo territories were only desired to counterbalance the predominantly Chinese population of Singapore. (Noordin Sopiee. 1970: 125-127).

\section{The Decolonization Theory}

This paper however is supporting the view that it was the broader theories of decolonization and expansionist nationalisms that become the foundation of Tunku's Malaysia. In this context it may be noted that a major impulse that drove Tunku to announce the Malaysia Scheme in 1961 was the desire to help complete the unfinished British Grand Design of decolonization which had been derailed as a result of Malaya's unexpected independence in 1957. When this Grand Design had to be aborted in 1957, Britain began to face an intractable dilemma of finding a workable solution for decolonizing the rest of her colonial possession in the region. The British found it unfeasible to grant independence separately to Singapore, North Borneo, Sarawak and Brunei as they were too small or too weak politically, economically and in security terms to survive alone. They were also extremely vulnerable to the forces of expanding communism, a situation the British colonial masters wished to avoid for the preservation of their own interests in the region. In the Borneo region the British tried to find a workable solution by fostering the formation of a North Borneo Federation from 1957 to 1960. This attempt however failed miserably due to the opposition of the Sultan of Brunei; the rise of Party Rakyat Brunei which wanted to establish Negara Kalimantan Utara linked to Indonesia; and the rising tide of communism in Sarawak spearheaded by the Sarawak Communist Clandestine Organization. The Singapore problem became even more 
alarming with the stark possibility of a communist take-over of the government in 1961. In these dire circumstances, the British began to look to Malaya and Tunku Abdul Rahman to help solve their decolonization problems (Nicholas Tarling. 2001. 132-135; Greg Poulgrain. 1998. 252-253; G.M. Kahin. 1964. 304-305). Tunku was quite ready to do the colonial job for the British, but had another motive as well for the creation of Malaysia. This second orientation was the desire for territorial expansion, an impulse very much consistent with the phenomena of expansionist nationalisms of the time, especially in insular Southeast Asia.

\section{Expansionist Nationalisms of Southeast Asia}

Paradoxically, the rise of nationalism in the Philippines, Indonesia, Brunei and the Federation of Malaya also produced a desire among the leaders of these countries for territorial expansion in the region for various reasons. This phenomena may be termed expansionist nationalisms. In the Philippines the main architect of this nationalist expansion was Diosdado Macapagal who, since the achievement of independence by the Philippines in 1946, began to campaign for the recovery of North Borneo by his country. He was extremely disturbed by the "annexation" of North Borneo by the British Government from the British North Borneo Company (BNBC) and its conversion to a Crown Colony in 1946. Macapagal had always entertained the notion that North Borneo was a lease made by the Sultan of Sulu in 1878 and that one day, the Philippine Government, as successor to the Sulu Sultanate, would be able to retake North Borneo from the BNBC. Now that North Borneo had become a British Crown Colony, the urgency of such a move become even more pronounced. Moreover the descendants of Sultan Jamalul Kiram of Sulu who had originally granted the Borneo territories to the Overbeck-Dent Association in 1878, were unhappy with the British Government which had stopped the payment of the annual lease monies to them since 1946. They had subsequently formed the Kiram Corporation to fight for their rights. Different lawyers fought their cases, including Nicasion Osmena who took over as their attorney in 1958. However the issue of the annual lease/ cession monies was not resolved. Meanwhile, Sukarno in Indonesia wanted to resurrect the Majapahit Empire and laid claim to all former Dutch colonies in the region, including West New Guinea (West Irian) which was not handed over by the Dutch to the Indonesian Republic in 1949. As mentioned earlier, Indonesia also had designs over British Borneo, over which it was casting "covetous eyes" as early as 1953 (Greg Poulgrain. 1998: 185-189, 231-235; D. G. E. Hall. 1981: 930-932). In the 1950s, therefore, there was a real possibility of a clash developing between the Philippines and Indonesia in the Borneo region. (Nicholas Tarling. 2001: 134-135.) The scenario suddenly took on a new turn when Tunku Abdul Rahman announced his Malaysia Scheme on 27 May 1961.

Tunku's Malaysia Scheme also smacked of expansionist aims. Tunku basically wanted North Borneo, Sarawak and Brunei as part of Greater Malaya. Tunku was willing to bring in Singapore only if the British Borneo territories were brought in first. His proposal, as Tunku recorded, took everyone by "storm" (Tunku Abdul Rahman Putra Al-Haj. 1977: 82.) The year 1961 was also elections year in the Philippines. Macapagal, who was vying for the Presidency, made the issue of taking back North Borneo a central theme of his campaign. Macapagal eventually won the election and became President of the Philippines on 30 December 1961. 
From henceforth, he began to pursue the retrieval of North Borneo with greater vehemence. Meanwhile, the Kiram Corporation, unable to make any headway on their own, handed over their case to the jurisdiction of the Philippine Government. Armed with this authority, the Philippine Government officially laid claim to North Borneo on 22 June 1962. (M. O. Ariff. 1970; Greg Poulgrain. 1998).

The possibility of a clash between the Philippines and Indonesia over the Borneo region deflected to opposition by these two countries to the Malaysia Scheme. While the Philippines laid an official claim to Sabah, Indonesia began to accuse Malaysia of being a neo-colonialist plot and vowed to crush the new entity. It soon launched an undeclared war called Confrontration, (1963-1966) which ended only in 1966 with the downfall of Sukarno. (J. A. C. Mackie, 1974). In Brunei, the Party Rakyat Brunei led by A. M. Azahari was seriously advocating the revival of the former Brunei Empire in the form of Negara Kalimantan Utara in the years 1956-1962 (D. S. Ranjit Singh. 1991). These expansionist nationalisms overlapped in the territorial milieu and produced a period of intense conflict. The concepts of Greater Malaya, Greater Brunei, Greater Indonesia and Greater Philippines were totally irreconcilable and thus produced political turmoil in the region. Despite the serious opposition from the Philippines, Indonesia and the Party Rakyat Brunei, Malaysia was neverthless formed on 16 September 1963, minus Brunei. It must however be pointed out here that Malaya's expansionist nationalism was to a large extent blunted by the exercise of self-determination by the population of Sabah and Sarawak who also obtained a number of safeguards for their states before agreeing to form the new federation of Malaysia. (Report of the Inter-Governmental Committee 1962).

\section{Conclusion}

As discussed in the paper, the Malaysia Scheme had its origins in British policy and the 'Grand Design' was formulated to complete the process of British decolonization in Southeast Asia. Eventually that is what Tunku's Malaysia helped to achieve. İn this context, the security theory is incidental; it just speeded up the process of British decolonization. The expansion theory is also inadequate in explaining the creation of Greater Malaya. It is used to explain Tunku's desire for territorial expansion in isolation, in terms of internal dynamics of balancing the indigenous population vis-a-vis the Chinese. Whereas the competing expansionist nationalism thesis is embedded in the emergence of a regional phenomena in post-independence Southeast Asia, especially the maritime countries, which led to a rush for 'grabbing' territory legitimately or otherwise. The creation of Greater Malaya therefore cannot be seen in isolation. İt was a part of a larger movement in the region at the time - the phenomena of expansionist nationalisms, though the concept of Greater Malaya was to a large extent modified by the desire of the people of Sabah and Sarawak themselves to form the new federation of Malaysia.

\section{References}

Abdul Rahman, T. P. (1977). Looking Back: Monday Musings and Memories. Kuala Lumpur: Pustaka Antara. 
Albert Lau (1991). The Malayan Union Controversy, 1942-1948. Singapore: Oxford University Press.

Ariff, M. O. (1970). The Philippines’ Claim to Sabah: Its Historical, Legal and Political Implications. Singapore: Oxford University Press.

Government of Malaya. (1962). Report of the Inter-Governmental Committee 1962. Kuala Lumpur: Government of Malaysia

Greg Poulgrain, (1998). The Genesis of Konfrontasi: Malaysia, Brunei and Indonesia, 1945-1965. Bathurst: Crawford House Publishing Pty Ltd.

Hall, D. G. E. (1964). A History of South-East Asia. London: Macmillan.

Kahin, G. M. (1967). Governments and Politics of Southeast Asia (ed.). New York: Cornell University Press.

Nicholas, T (2001). South East Asia: A Modern History. South Melbourne: OUP Australia and New Zealand.

Ongkili, J. P. (1967). The Borneo Response to Malaysia, 1961-1963. Singapore: Donald Moore Press.

Ranjit Singh, D. S. (1991). Brunei, 1839-1983: The Problems of Political Survival. Singapore: Oxford University Press.

Ranjit Singh, D. S. (1998). British Proposals For A Dominion of Southeast Asia, 1943-1957. Journal of the Malaysian Branch of the Royal Asiatic Society, 71(1) (274), 27-40.

Ranjit Singh, D. S. (2011). The Making of Sabah, 1865-1941: The Dynamics of Indigenous Society. Kota Kinabalu: Sabah State Government.

Records of the Colonial Office, Proposal for Closer Political Association between Colonial Territories in South-East Asia (C.O. 1022/61). London: British National Archives

Sopiee, M. N. (1974). From Malayan Union to Singapore Separation: Political Unification in the Malaysia Region. Kuala Lumpur: University Malaya Press.

Stockwell, A. J. (1979). British Policy and Malay Politics During the Malayan Union Experiment 1942-1948. Kuala Lumpur: The Malaysian Branch of the Royal Asiatic Society. Monograph No:8.

Warren, J. F. (1981). The Sulu Zone, 1768-1898: The Dynamics of External Trade, Slavery and Ethinicity in the Transformation of a Southeast Asian Maritime State. Singapore: National University of Singapore Press.

\section{Copyright Disclaimer}

Copyright for this article is retained by the author(s), with first publication rights granted to the journal.

This is an open-access article distributed under the terms and conditions of the Creative Commons Attribution license (http://creativecommons.org/licenses/by/3.0/). 